Article

\title{
Analyzing the Tourism-Energy-Growth Nexus for the Top 10 Most-Visited Countries
}

\author{
Cem Işik ${ }^{1, *}$, Eyüp Doğan ${ }^{2}$ and Serdar Ongan ${ }^{3}$ \\ 1 Department of Tourism Management, Atatürk University, 25240 Erzurum, Turkey; isikc@atauni.edu.tr \\ 2 Department of Economics, Abdullah Gül University, 38080 Kayseri, Turkey; eyup.dogan@agu.edu.tr \\ 3 Department of Economics, St. Mary's College of Maryland, St. Mary's City, MD 20686, USA; \\ songan@smscm.edu \\ * Correspondence: isikc@atauni.edu.tr; Tel.: +90 4422315043
}

Academic Editor: Juan Ignacio Pulido-Fernández

Received: 6 September 2017; Accepted: 18 October 2017; Published: 30 October 2017

\begin{abstract}
By using the Emirmahmutoglu-Kose bootstrap Granger non-causality method, this study explores the directions of causality among tourist arrivals, tourism receipts, energy consumption and economic growth for the top 10 most-visited countries (France, the USA, Spain, China, Italy, Turkey, Germany, the United Kingdom, Russia, and Mexico) in the world. This study finds a variety of causal directions between the pair of analyzed variables for each country and the panel. Since cross-sectional dependence exists across the top countries for the analyzed variables, the bootstrap Granger causality test that accounts for the mentioned issue in the estimation process presumably produces reliable and accurate outputs. Further results and policy implications are discussed in this empirical study.
\end{abstract}

Keywords: Granger causality; tourist arrivals; tourism receipts; energy consumption; economic growth; the top 10 most-visited countries

JEL Classification: C1; N7; O11; O13; O40

\section{Introduction}

A general idea has emerged in the last decade: that tourism flows and energy consumption increase revenue, produce growth, create employment in tourism and energy sectors and cause a general improvement in economic development (Crouch and Ritchie 1999). Currently, both energy and tourism are related to sustainability of the economy in the world. (Daly 1991; Hall and Page 2014). According to the U.S. Energy Information Administration (EIA), world consumption of marketed energy will increase from 549 quadrillion British thermal units (Btu) in 2012 to 815 quadrillion Btu in 2030 (EIA 2016). Similarly, the United Nations World Tourism Organization (UNWTO) projects that world international tourist arrivals will increase from 1.0 billion in 2012 to 1.8 billion in 2030 (UNWTO 2013). Especially in developing countries, tourism flows and energy consumption can impact positively on the trade balance, employment and limited resources of host countries. (Daly 1991; Asif and Muneer 2007; Isik 2012, 2013; Hall and Page 2014; Dogan et al. 2015; Isik, 2015; Isik and Shahbaz 2015; Dogan and Seker 2016; Ertugrul et al. 2016; Isik et al., 2017b, 2017a).

With the continual increase in tourism and travel activities globally, there are serious allegations that the industry is significantly contributing towards climate change through its impact on $\mathrm{CO} 2$ emissions (Sharpley and Telfer 2015). According to Karabuğa et al. (2015), 90\% of energy consumption occurs during outgoing and incoming to destinations ( $43 \%$ airway, $42 \%$ land transport, $15 \%$ sea and railways). Tourism sector has a $5 \%$ of worldwide carbon dioxide (CO2) emission. These impacts might be reduced if proper courses of actions are to be taken (Dogru et al. 2016) The current literature recommends 
reducing the consumption of traditional energy resources while increasing the use of renewable or alternative energy for sustainable economic growth and tourism development (Scott and Becken 2010; Jenkins and Nicholls 2010). Renewable energy resources (Solar Energy, Biomass Energy, Heat Pump, Wind Power and Geothermal Energy etc.) are the most suitable energy forms for clean environment concept that do not pollute during the production and renew it (Karabuğa et al. 2015).

The developed countries that are the main generators of tourists, much more attention has been given to tourism development theory in the context of the less developed world. Nevertheless, the developed countries relatively reach major benefits from the tourism. While less developed countries' contribution to energy due to tourism activities is smaller compared to developed countries (Sharpley and Telfer 2015). In especial, the tourism sector has shown an exceptional improvement in France, the USA, Spain, China, Italy, Turkey, Germany, the United Kingdom, Russia, and Mexico, which are the top ten most-visited countries in terms of tourist arrivals in 2014. Table 1 shows tourist arrivals, tourism receipt, energy consumption and GDP statistics for the top 10 most-visited countries in the world for the latest available year.

Table 1. Tourist Arrivals, Tourism Receipt, Energy Consumption and GDP of the Top 10 most-Visited Countries.

\begin{tabular}{ccccc}
\hline $\begin{array}{c}\text { Top 10 Most-Visited } \\
\text { Countries (2014) }\end{array}$ & $\begin{array}{c}\text { Int. Tourist Arrivals } \\
\text { (Million People } \\
\text { Ranking, 2014) }\end{array}$ & $\begin{array}{c}\text { Int. Tourism Receipt } \\
\text { (Billion USD, 2014) }\end{array}$ & $\begin{array}{c}\text { Energy Consumption } \\
\text { (Quadrillion Btu, 2013) }\end{array}$ & $\begin{array}{c}\text { GDP (2014) (The Real } \\
\text { Gross Domestic Product } \\
\text { Constant in 2005 USD) }\end{array}$ \\
\hline France & $83.7(1)$ & 55.4 & 10.7 & $2,829,192$ \\
The USA & $74.8(2)$ & 177.2 & 95.05 & $17,419,000$ \\
Spain & $66.0(3)$ & 65.2 & 6.02 & $1,381,342$ \\
China & $55.6(4)$ & 56.9 & 105.88 & $10,354,832$ \\
Italy & $48.6(5)$ & 45.5 & 7.17 & $2,141,161$ \\
Turkey & $39.8(6)$ & 43.3 & 5.05 & 798,429 \\
Germany & $33.0(7)$ & 43.3 & 13,47 & $3,868,291$ \\
The UK & $32.6(8)$ & 45.3 & 31.52 & $2,988,893$ \\
Russia & $29.8(9)$ & 11.7 & 7.75 & $1,860,598$ \\
Mexico & $29.1(10)$ & 17,4 & 291.24 & $1,294,690$ \\
Total & 493 & 561.2 & 524.08 & $44,936,428$ \\
World & 1113 & 1245 & $56 \%$ & 77,609 Trillion USD \\
Top 10's share & $44 \%$ & $45 \%$ & $58 \%$ \\
\hline
\end{tabular}

( ) denotes the ranks of the countries. Source: World Bank, World Development Indicators (WDI 2016). UNWTO (2013),

(United Nations World Tourism Organization), World Tourism Trends. British Petroleum Energy Outlook (2015). EIA (2016), International Energy Agency.

According to the World Development Indicators (WDI) (2016), the top 10 most-visited countries (France, the USA, Spain, China, Italy, Turkey, Germany, the United Kingdom, Russia, and Mexico) reached 44.936 billion USD GDP in 2014 (with a share of $58 \%$ of total world GDP). These countries total trade was close to 1.657 trillion USD, exports were 7.828 billion USD and imports were 8.739 billion USD. The top 10 most-visited countries' economies reached an annual average growth rate of $2.00 \%$ as of 2014. The tourism receipt for the top 10 most-visited countries was 561.2 billion USD in 2014 and 660.8 billion USD in 2013. The international tourism receipt for the analyzed countries reached an annual average growth rate of $18 \%$ as of 2014 . Energy consumption in these countries is increasingly growing in the last decade and reached 524.08 quadrillion Btu (British thermal unit) in 2013. It was more than half of the world's energy consumption (56\% in 2013). The top 10 countries' energy consumption was 291.24 quadrillion Btu of the world total 524.08 quadrillion Btu in 2013 (British Petroleum Energy Outlook 2015).

The purpose of this study is to investigate the causal relationships between tourism development, energy consumption and real GDP (economic growth). For this purpose, the Bootstrap Panel Granger causality test is used to examine the causal link between tourism, energy consumption and real GDP, in France, the USA, Spain, China, Italy, Turkey, Germany, the United Kingdom, Russia, and Mexico. The top 10 most-visited countries offer a unique setting to investigate the causal relationship between tourism development, economic growth, and energy consumption because of their respective shares of world's tourism development, GDP and energy consumption. 
This research contributes to the existing literature in several aspects. The investigation of the top countries is of interest to policy makers and governments as they play important roles in energy and tourism sectors and in the overall world economy upon aforementioned discussions. This study uses the recently developed Emirmahmutoglu-Kose bootstrap panel Granger causality test which accounts for the issue of cross-sectional dependence, since we find that the issue appears in the analyzed data. The reported results are thus reliable and robust, and strong for policy implications.

The rest of this paper is systematized as follows. Section 2 presents the main findings of the previous studies on this nexus, Section 3 defines the methodology, Section 4 discusses the empirical results and finally, Section 5 elaborates upon the conclusions and policy recommendations.

\section{Literature Review}

The tourism and energy consumption and their relation with economic growth is not involved in many studies until recent years. Some early works have focused on tourism economics or energy economics itself. Few studies use these two variables which affect economic growth in one equation. The impact of the tourism and energy consumption on economic growth has not always been well argued in the economic literature.

It is appropriate for our study to begin investigating the literature that has stressed the link between the tourism-energy-growth. There are some earlier studies on energy consumption, the tourism sector and economic growth (Oh et al. 2010; Akbostanc1 et al. 2011; Liu et al. 2011; O'Mahony et al. 2012; Pardo et al. 2012; Pace 2015; Moutinho et al. 2015; Isik et al., 2017b, 2017a). We also discovered different works in the tourism literature that have examined the energy and $\mathrm{CO}_{2}$ emissions (Liu et al. 2011; Scott 2011; Wu and Shi 2011; Lee and Brahmasrene 2013; Lee and Kwag 2013; Katircioglu et al. 2014).

The actual literature focused on the energy-growth relation displays a wide variety of result. Today, the energy - growth connection has widely been empirically examined since the study of Kraft and Kraft. The general results of the current works on energy consumption are not uniform. Some different econometric technics were used (unit root tests, cointegration tests, etc.) to identify the causality direction between these variables (Shahbaz and Lean 2012).

We have also studied the main findings of the economic literature for the impact of energy consumption and tourism flows on economic growth as shown in Table 2 (Energy, Tourism Economic Growth Causality). Based on the results, we can classify the research into four acceptable theories; growth, conservation, feedback and neutrality theory.

Table 2. Energy, Tourism and Economic Growth Causality.

\begin{tabular}{|c|c|c|c|c|c|}
\hline Author & Time & Destination & Methodology & Variables & Causality \\
\hline \multicolumn{6}{|c|}{ Energy/Tourism-Led Growth } \\
\hline Isik et al. (2017a) & 1970-2014 & Greece & $\begin{array}{l}\text { Zivot Andrews unit rooti } \\
\text { ARDL, Granger Causality }\end{array}$ & ARRV/RCPT\&Y\&CO2\&FD\&I & $\begin{array}{c}\mathrm{ARRV} / \mathrm{RCPT} \rightarrow \mathrm{CO}_{2} \\
\mathrm{FD} \rightarrow \mathrm{CO}_{2}, \mathrm{I} \rightarrow \mathrm{CO}_{2} \\
\mathrm{Y} \rightarrow \mathrm{CO}_{2}\end{array}$ \\
\hline Ozturk (2016) & & $\begin{array}{l}\text { The panel of selected } \\
34 \text { countries }\end{array}$ & FMOLS & ARRV/RCPT\&Y\&EGY & $\begin{array}{l}\text { EGY exerts a negative } \\
\text { association with the } \\
\text { ARRV/RCPT }\end{array}$ \\
\hline Dogan (2015) & 1990-2012 & Turkey & ARDL & EGY \& Y & $\begin{array}{l}\text { EGY } \propto Y \text { in the short run } \\
E G Y \rightarrow Y \text { in the long run }\end{array}$ \\
\hline $\begin{array}{c}\text { Rezitis and } \\
\text { Ahammad (2015) }\end{array}$ & 1990-2012 & $\begin{array}{l}\text { South and Southeast } \\
\text { Asian Countries }\end{array}$ & $\begin{array}{l}\text { Panel Unit Root LLC and } \\
\text { Breitung Tests, Panel Unit } \\
\text { Root HT and IPS, Panel } \\
\text { Co-integration: Panel } \\
\text { FMOLS and DOLS }\end{array}$ & EGY \& Y & $\mathrm{EGY} \rightarrow \mathrm{Y}$ \\
\hline
\end{tabular}


Table 2. Cont.

\begin{tabular}{|c|c|c|c|c|c|}
\hline Author & Time & Destination & Methodology & Variables & Causality \\
\hline \multicolumn{6}{|c|}{ Energy/Tourism-Led Growth } \\
\hline $\begin{array}{l}\text { Leon et al. } \\
\text { (2014) }\end{array}$ & 1998-2006 & $\begin{array}{c}14 \text { Developed, } 31 \text { less } \\
\text { developed }\end{array}$ & $\begin{array}{l}\text { The Generalized Method of } \\
\text { Moments, GLS }\end{array}$ & $\begin{array}{c}\text { ARRV/RCPT } \\
\& Y \& \mathrm{CO}_{2} \& \text { Population\&E }\end{array}$ & $\begin{array}{l}\text { Tourism has pozitive } \\
\text { effect on } 14 \text { developed } \\
\text { and } 31 \text { less } \\
\text { developed countries }\end{array}$ \\
\hline $\begin{array}{l}\text { Adhikari and } \\
\text { Chen (2013) }\end{array}$ & 1990-2009 & $\begin{array}{l}80 \text { Developing } \\
\text { countries }\end{array}$ & $\begin{array}{l}\text { Panel Unit Root, Panel } \\
\text { Cointegration and Panel } \\
\text { Dynamic Ordinary Least } \\
\text { Squares (DOLS) }\end{array}$ & EGY \& Y & $\mathrm{EGY} \rightarrow \mathrm{Y}$ \\
\hline Kareem (2013) & 1990-2011 & Africa & $\begin{array}{c}\text { Levin, Lin and Chu, Im, } \\
\text { Pesaran and Shin } \\
\text { Hadri Z, Pedroni }\end{array}$ & ARRV/RCPT \&Y\&others & $\mathrm{ARRV} / \mathrm{RCPT} \rightarrow \mathrm{Y}$ \\
\hline Isik (2010) & 1977-2008 & Turkey & ARDL & EGY \& Y & $\begin{array}{l}\mathrm{EGY} \rightarrow \mathrm{Y} \text { in the } \\
\text { short run }\end{array}$ \\
\hline $\begin{array}{l}\text { Cortes-Jimenez } \\
\text { and Pulina } \\
\text { (2010) }\end{array}$ & 1954-2000 & Italy \& Spain & $\begin{array}{l}\text { VECM, Johansen } \\
\text { Cointegration }\end{array}$ & ARRV/RCPT \&Y\&C & $\mathrm{ARRV} / \mathrm{RCPT} \rightarrow \mathrm{Y}$ \\
\hline \multicolumn{6}{|c|}{ Growth-Led Energy/Tourism } \\
\hline $\begin{array}{l}\text { Isik et al. } \\
\text { (2017a) }\end{array}$ & & Top 7 & $\begin{array}{l}\text { ADF, PP, Nonlinear Unit } \\
\text { Root, Panel Co-integration, } \\
\text { Bootstrap }\end{array}$ & ARRV/RCPT\&Y\&EGY & $\begin{array}{c}\text { EGY } \rightarrow \text { Y (Spain); } \\
\text { ARRV / RCPT } \rightarrow \text { Y } \\
\text { (China, Turkey); } \\
\text { ARRV/RCPT } \rightarrow \text { EGY } \\
\text { (Italy, Spain, Turkey } \\
\text { and United States) }\end{array}$ \\
\hline $\begin{array}{l}\text { Azam et al. } \\
(2015 b)\end{array}$ & 1980-2012 & $\begin{array}{l}\text { Indonesia, Malaysia } \\
\text { and Thailand }\end{array}$ & $\begin{array}{l}\text { CSUSM and SUCUSM Park, } \\
\text { ADF for Stationary: } \\
\text { Least square }\end{array}$ & EGY \& Y & $\begin{array}{l}\text { Y } \rightarrow \text { EGY (Indonesia, } \\
\text { Malaysia and Thailand) }\end{array}$ \\
\hline $\begin{array}{l}\text { Azam et al. } \\
(2015 a)\end{array}$ & 1980-2012 & $\begin{array}{l}\text { Indonesia, Malaysia, } \\
\text { Philippines, Singapore } \\
\text { and Thailand }\end{array}$ & $\begin{array}{l}\text { ADF Unit Root, } \\
\text { Cointegration, Pearson } \\
\text { Correlation Analysis, } \\
\text { Granger Causality }\end{array}$ & EGY \& Y & $\begin{array}{c}\text { Y } \rightarrow \text { EGY (Malaysia) } \propto \\
\text { (Indonesia, Philippines, } \\
\text { Singapore and Thailand) }\end{array}$ \\
\hline $\begin{array}{l}\text { He and Zheng } \\
\text { (2011) }\end{array}$ & 1990-2009 & China (Sichuan) & VECM & ARRV/RCPT\&Y & $\mathrm{Y} \rightarrow \mathrm{ARRV} / \mathrm{RCPT}$ \\
\hline $\begin{array}{l}\text { Ozturk et al. } \\
\quad(2010)\end{array}$ & 1971-2005 & $\begin{array}{l}51 \text { Low and middle } \\
\text { income countries }\end{array}$ & $\begin{array}{l}\text { IPS Panel Unit Root, Panel } \\
\text { Co-integration, Panel } \\
\text { Granger Causality, Panel } \\
\text { FMOLS and DOLS }\end{array}$ & EGY \& Y & $\begin{array}{c}\text { Y } \rightarrow \text { EGY (low income } \\
\text { countries) EGY } \leftrightarrow \text { Y } \\
\text { (middle income } \\
\text { countries) }\end{array}$ \\
\hline \multicolumn{6}{|c|}{ No Causality } \\
\hline Jin (2011) & 1974-2004 & Hong Kong & $\begin{array}{c}\text { VECM, Variance } \\
\text { Decompositions (VDCs) }\end{array}$ & ARRV/RCPT\&Y & Q \\
\hline \multicolumn{6}{|c|}{ Bidirectional Causality } \\
\hline $\begin{array}{l}\text { Dogru and } \\
\text { Bulut (2017) }\end{array}$ & 1996-2014 & 7 EU Countries & CADF panel unit root tes & ARRV/RCPT\&Y & $\mathrm{Y} \leftrightarrow \mathrm{ARRV} / \mathrm{RCPT}$ \\
\hline $\begin{array}{l}\text { Al-mulali et al. } \\
\text { (2014) }\end{array}$ & 1985-2012 & Middle East & $\begin{array}{c}\text { Pedroni } \\
\text { Cointegration/VECM }\end{array}$ & $\begin{array}{c}\text { ARRV/RCPT \&Y\&Real } \\
\text { Exchange Rate\&Total Trade }\end{array}$ & $\mathrm{Y} \leftrightarrow \mathrm{ARRV} / \mathrm{RCPT}$ \\
\hline $\begin{array}{l}\text { Tang and } \\
\text { Abosedra } \\
(2014)\end{array}$ & 2001-2009 & MENA & $\begin{array}{l}\text { Static Panel Estimation, } \\
\text { Arellano-Bond Dynamic } \\
\text { GMM Estimation }\end{array}$ & $\begin{array}{l}\text { EGY, Y, ARRV /RCPT, } \\
\text { Poliitical Stability, C }\end{array}$ & $\mathrm{EGY} \leftrightarrow \mathrm{Y}$ \\
\hline $\begin{array}{l}\text { Lee and } \\
\text { Brahmasrene } \\
\text { (2013) }\end{array}$ & 1988-2005 & EU countries & $\begin{array}{l}\text { Pearson Correlation } \\
\text { Analysis, Unit Root, } \\
\text { Johansen Panel } \\
\text { Cointegration }\end{array}$ & $\begin{array}{l}\mathrm{ARRV} / \mathrm{RCPT} \& \mathrm{Y} \\
\mathrm{E} \& \mathrm{CO}_{2} \& \mathrm{FDI}\end{array}$ & $\begin{array}{l}\mathrm{ARRV} / \mathrm{RCPT} \rightarrow \mathrm{Y} \mathrm{Y} \rightarrow \\
\mathrm{CO}_{2}, \mathrm{EGY} \text { Tourism does } \\
\text { not cause an increase of } \\
\mathrm{CO}_{2} \text { emmissions FDI } \rightarrow \\
\text { Y FDI cause a decrease } \\
\text { of } \mathrm{CO}_{2} \text { emissions }\end{array}$ \\
\hline $\begin{array}{l}\text { Tiwari et al. } \\
\text { (2013) }\end{array}$ & 1995-2005 & OECD & Panel VAR & ARRV/RCPT\&EGY\&CO 2 & EGY $\leftrightarrow$ ARRV/RCPT \\
\hline $\begin{array}{c}\text { Kadir and } \\
\text { Karim (2012) }\end{array}$ & 1998-2005 & ASEAN & $\begin{array}{l}\text { Pedroni Cointegration/ } \\
\text { VECM }\end{array}$ & ARRV/RCPT\&Y & $\mathrm{Y} \leftrightarrow \mathrm{ARRV} / \mathrm{RCPT}$ \\
\hline \multicolumn{6}{|c|}{$\begin{array}{l}\text { GDP = Y, EGY = Energy Consumption, ARRV } / \mathrm{RCPT}=\text { Tourism, C = capital, } \mathrm{CO}_{2}=\text { Carbon Dioxide, } \mathrm{I}=\text { International } \\
\text { Trade, FD = Financial Development, Emission, ECM = Error Correction Model, JJ = Johansen-Juselius, VEC = Vector } \\
\text { Error Correction Model, DOLS = The Panel Dynamic Ordinary Least Squares FMOLS = the Fully-Modified Ordinary } \\
\text { Least Squares, GMM = The Dynamic Generalised Method of Moments, ARDL = Autoregressive Distributed Lag, } \\
\text { GLS = Generalized Least Squares, DF = Dickey Fullers, LLC = Levin-Lin-Chu Test, IPS = The Im-Pesaran-Shin } \\
\text { Test, HT = Harris-Tsavalis Test, CUSUM = Cumulative Sum, CUSUSQ = Cumulative Sum of Squares, } \\
\text { PP = Phillips-Perron, KPSS = Kwiatkowski-Phillips-Schmidt-Shin, HEGY = the Hylleberg-Engle-Granger-Yoo, } \\
\text { VDC = Variance Decompositions and } \rightarrow, \leftarrow, \leftrightarrow, \otimes \text { shows unidirectional causality, bidirectional causality, and no } \\
\text { causality, respectively. }\end{array}$} \\
\hline
\end{tabular}

It is generally agreed that tourism and energy plays a robust role for both the income and the expenditure and investment of goods and services within an economy. In light of these findings, 
the mission of this section is to ensure a review of the previous studies on the causal link between tourism, energy and growth. In the related literature, there have been more studies that have applied Granger causality tests to investigate the causal relationships for tourism development or energy consumption with economic growth as pairs. For instance, while Aqeel and Butt (2008) apply the Hsiao's Granger causality test for Pakistan, Wolde-Rufael (2004) applies the Toda and Yamamoto (1995) causality test and they both find causal relationships from energy consumption to the economic growth. However, Ozturk et al. (2010) apply the Panel Granger causality test on 51 low and middle-income countries and find the same relationship from the economic growth to energy consumption. Furthermore, while Chen et al. (2007) apply the Panel causality for China and find no causal relationships between energy consumption and economic growth, Yuan et al. (2007) apply the Granger causality for the same country and find bidirectional causality between these two variables.

\section{Model and Data}

Following studies Lee and Brahmasrene (2013), Tiwari et al. (2013), Leon et al. (2014), and Tang et al. (2016) that focus on the link of tourism-energy-growth nexus, this study uses the following models where economic growth $(Y)$ is the dependent variable, and energy consumption (EGY) and tourism are the independent variables. We used E-Views 8 econometric software for the estimations. To check the robustness of the direction of causality between tourism and economic growth, we employ both tourist arrivals (ARRV) and tourism receipt (RCPT). The models can be written as:

$$
\text { Model 1: } Y_{i t}=f\left(\mathrm{EGY}_{i t}, \mathrm{ARRV}_{i t} / \mathrm{RCPT}_{i t}\right)
$$

where $t$ and $i$ denote the time period and country. According to the World Development Indicators (WDI) (2016), the world's 10 most-visited countries are France, the US, Spain, China, Italy, Turkey, Germany, the UK, Russia and Mexico. ${ }^{1}$ Regarding data description, economic growth $(Y)$ is measured by the real gross domestic product constant in 2005 USD; energy consumption (EGY) is shown in kg of oil equivalent; tourist arrival (ARRV) equals the number of international inbound tourists; tourism receipts (RCPT) are measured by expenditures by international inbound tourists constant in 2005 USD. The annual data for the analyzed variables from 1995-2013 are sourced from the WDI (2016). It is worth that we use available data with the longest time period.

\section{Methods and Empirical Results}

As it is the main research proposal of this study to investigate the directions of causality among economic growth, energy consumption and tourism, we should find an appropriate and reliable estimation technique. One of the commonly observed but ignored issues in the literature is the presence of cross-sectional dependence across countries for panel data. Besides, traditional Granger causality approaches such as pair-wise Granger causality test and Granger causality based on vector error correction mechanism, this may produce inconsistent output because they do not take into account the issue of cross-sectional dependence. In the existence of cross-sectional dependence, we should employ a second generation Granger causality method robust enough to handle this issue. To this end, we analyze whether or not the analyzed variables include cross-sectional dependence by using the Pesaran's cross-sectional dependence (CD) test (Pesaran 2004).

Results from the CD-test are reported in Table 3. We have enough evidence to reject the null hypothesis of cross-sectional independence in favor of the alternative hypothesis of cross-sectional dependence across the top 10 most-visited countries for economic growth, energy consumption, tourist arrivals and tourism receipts at $1 \%$ level of significance. This study, according to the reported results, would rather use the bootstrap methodology to Granger causality test for cross-sectionally dependent

1 The data are available at http:// data.worldbank.org/. 
panels developed by Emirmahmutoglu and Kose (2011) than the above mentioned traditional ones. The Emirmahmutoglu-Kose bootstrap causality test builds on the Meta analysis of Fisher (Fisher 1932) and the idea of vector autoregression (VAR) with lag order and the maximal order of integration due to Toda and Yamamoto (1995). To test the null hypothesis of non-Granger causality, the authors estimated a level of VAR with lag order $\left(\mathrm{k}_{\mathrm{i}}\right)$ and the maximum order of integration of variables $\left(\mathrm{dmax}_{\mathrm{i}}\right)$ in heterogonous mixed panels. ${ }^{2}$ The only prior information needed is dmax $_{i}$ suspected to happen in the system for each country.

Table 3. Cross-sectional independence test.

\begin{tabular}{ccccc}
\hline & Y & EGY & ARRV & RCPT \\
\hline CD-test & $27.00 *$ & $7.18^{*}$ & $23.77^{*}$ & $5.56^{*}$ \\
$p$-value & 0.00 & 0.00 & 0.00 & 0.00 \\
\hline \multicolumn{4}{c}{ * denotes the statistical significance at $1 \%$ level. }
\end{tabular}

By following the original study, we applied the Augmented Dickey-Fuller (ADF) unit root test (Dickey and Fuller, to the analyzed time-series data so as to determine the maximum number of integration). Moreover, we also used the Phillips-Perron unit root test for the purpose of robustness. Results from the ADF unit root test and the Phillips-Perron unit root tests are given in Tables 4 and 5 , respectively. Both tests virtually produce the same order of integration of analyzed variables. Overall, the maximum order of integration (dmax) is determined to be two for each variable for the panel.

Table 4. Augmented Dickey-Fuller (ADF) unit root test.

\begin{tabular}{|c|c|c|c|c|c|c|c|c|}
\hline & \multicolumn{3}{|c|}{$\mathbf{Y}$} & \multicolumn{5}{|c|}{ EGY } \\
\hline & Level & 1st difference & 2nd difference & $\operatorname{dmax}_{i}$ & Level & 1st difference & 2nd difference & $\operatorname{dmax}_{i}$ \\
\hline China & 0.92 & 0.45 & 0.01 & 2 & 0.97 & 0.28 & 0.01 & 2 \\
\hline Germany & 0.59 & 0.01 & - & 1 & 0.95 & 0.00 & - & 1 \\
\hline Italy & 0.20 & 0.08 & 0.00 & 2 & 0.79 & 0.07 & 0.00 & 2 \\
\hline Mexico & 0.34 & 0.02 & - & 1 & 0.76 & 0.00 & - & 1 \\
\hline Turkey & 0.90 & 0.01 & - & 1 & 0.87 & 0.00 & - & 1 \\
\hline UK & 0.12 & 0.16 & 0.00 & 2 & 0.99 & 0.00 & - & 1 \\
\hline \multirow[t]{3}{*}{ USA } & 0.04 & - & - & 0 & 0.18 & 0.01 & - & 1 \\
\hline & \multicolumn{3}{|c|}{ ARRV } & \multicolumn{5}{|c|}{ RCPT } \\
\hline & Level & 1st difference & 2nd difference & $\operatorname{dmax}_{i}$ & Level & 1st difference & 2nd difference & $\operatorname{dmax}_{i}$ \\
\hline Mexico & 0.77 & 0.00 & - & 1 & 0.16 & 0.03 & - & 1 \\
\hline Russia & 0.01 & - & - & 0 & 0.04 & - & - & 0 \\
\hline Spain & 0.15 & 0.14 & 0.00 & 2 & 0.05 & - & - & 0 \\
\hline Turkey & 0.87 & 0.00 & - & 1 & 0.91 & 0.00 & - & 1 \\
\hline UK & 0.87 & 0.06 & 0.00 & 2 & 0.98 & 0.07 & 0.00 & 2 \\
\hline USA & 0.95 & 0.03 & - & 1 & 0.93 & 0.01 & - & 1 \\
\hline
\end{tabular}

2 Please refer to the original study by Emirmahmutoglu and Kose (2011) for detailed information. 
Table 5. Phillips-Perron unit root test.

\begin{tabular}{|c|c|c|c|c|c|c|c|c|}
\hline & \multicolumn{3}{|c|}{$\mathbf{Y}$} & \multicolumn{5}{|c|}{ EGY } \\
\hline China & 0.97 & 0.39 & 0.01 & 2 & 0.99 & 0.32 & 0.00 & 2 \\
\hline Germany & 0.29 & 0.00 & - & 1 & 0.68 & 0.00 & - & 1 \\
\hline Italy & 0.21 & 0.09 & 0.00 & 2 & 0.69 & 0.08 & 0.00 & 2 \\
\hline Mexico & 0.36 & 0.02 & - & 1 & 0.74 & 0.00 & - & 1 \\
\hline Turkey & 0.90 & 0.01 & - & 1 & 0.88 & 0.00 & - & 1 \\
\hline UK & 0.12 & 0.17 & 0.00 & 2 & 0.95 & 0.00 & - & 1 \\
\hline \multirow[t]{3}{*}{ USA } & 0.04 & - & - & 0 & 0.18 & 0.01 & - & 1 \\
\hline & \multicolumn{3}{|c|}{ ARRV } & \multicolumn{5}{|c|}{ RCPT } \\
\hline & Level & 1st difference & 2nd difference & $\operatorname{dmax}_{i}$ & Level & 1st difference & 2nd difference & $\operatorname{dmax}_{i}$ \\
\hline Mexico & 0.83 & 0.00 & - & 1 & 0.30 & 0.03 & - & 1 \\
\hline Russia & 0.02 & - & - & 0 & 0.00 & - & - & 0 \\
\hline Spain & 0.15 & 0.14 & 0.00 & 2 & 0.04 & - & - & 0 \\
\hline Turkey & 0.90 & 0.00 & - & 1 & 0.74 & 0.00 & - & 1 \\
\hline UK & 0.73 & 0.06 & 0.00 & 2 & 0.95 & 0.05 & - & 1 \\
\hline USA & 0.94 & 0.03 & - & 1 & 0.95 & 0.01 & - & 1 \\
\hline
\end{tabular}

The next step is to reveal the directions of bootstrap panel Granger causalities for the pairs of economic growth-energy consumption, economic growth-international tourist arrivals, economic growth-international tourism receipts, international tourist arrivals-energy consumption and international tourism receipts-energy consumption. The empirical results of the bootstrap panel Granger causality test for each pair of variables and the panel are reported in detail in Tables A1-A5 in the Appendix A.

In conjunction with the information upon the number of integration for the analyzed variables, this study further looks at the direction of Granger causality between economic growth and energy consumption, between economic growth and tourist arrivals, between economic growth and tourism receipts, between tourist arrivals and energy consumption, and between tourism receipts and energy consumption. Results from the bootstrap Granger causality test due to Emirmahmutoglu and Kose (2011) for each pair of variables are reported in detail in the Appendix A. Nevertheless, Table 6 shows the summary of the outcomes obtained from the bootstrap causality method. In regards to the causal relationship, we found a one-way causal relationship running from energy consumption to economic growth (energy-led growth hypothesis) in Spain, and running from economic growth to energy consumption (growth-led energy hypothesis) in China, Turkey and Germany. We found a two-way causal relationship between energy consumption and economic growth in Italy, the USA and the panel of the top 10 most-visited countries, and no causal relationship between economic growth and energy consumption in France, Mexico, Russia and the UK. Furthermore, we found unidirectional causality from tourist arrivals to economic growth (tourism-led growth hypothesis) in China, Turkey and the panel, and from economic growth to tourist arrivals (growth-led tourism hypothesis) in Russia and Spain, bidirectional causality between economic growth and tourist arrivals in Germany, and no causality between them in France, Italy, Mexico, the UK and the USA. The evidence of one-way causality running from tourist arrivals to energy consumption (tourism-led energy hypothesis) is detected for Italy, Spain, Turkey, the UK and the USA while energy-led tourism hypothesis is held for China and Mexico. Moreover, two-way Granger causality is found for the panel of the analyzed economies, and no causality is valid for France, Germany and Russia. In addition, we found the presence of unidirectional causality from tourism receipts to economic growth in China, Germany, Turkey and the USA, and the presence of growth-led tourism hypothesis for Spain and the UK, the presence of both hypothesis for the panel, and the presence of no Granger causality in France, Italy, Mexico and Russia. Lastly, there is evidence for one-way Granger causality running from tourism receipts to energy consumption (tourism-led energy hypothesis) in Turkey and the USA, and running 
from energy to receipts (energy-led tourism hypothesis) in China, Mexico, Spain and the UK, evidence of two-way causality between energy and receipts for the panel of the top ten countries, and no causal relationship between them in France, Germany, Italy and Russia.

Table 6. Results from Emirmahmutoglu-Kose test.

\begin{tabular}{|c|c|}
\hline \multicolumn{2}{|c|}{ Granger Causality between Energy Consumption and Economic Growth } \\
\hline Energy-led growth & Spain \\
\hline Growth-led energy & China, Turkey and Germany \\
\hline Bidirectional causality & Italy, the USA and the panel of the analyzed countries \\
\hline No causality & France, Mexico, Russia and the UK \\
\hline \multicolumn{2}{|c|}{ Granger Causality between Tourist Arrivals and Economic Growth } \\
\hline Tourism-led growth, & China, Turkey and the panel of the analyzed countries \\
\hline Growth-led tourism & Russia and Spain \\
\hline Bidirectional causality & Germany \\
\hline No causality & France, Italy, Mexico, the UK and the USA. \\
\hline \multicolumn{2}{|c|}{ Granger Causality between Energy Consumption and Tourist Arrivals } \\
\hline Tourism-led energy & Italy, Spain, Turkey, the UK and the USA \\
\hline Energy-led tourism & China, Mexico \\
\hline Bidirectional causality & The panel of the analyzed countries \\
\hline No causality & France, Germany and Russia \\
\hline \multicolumn{2}{|c|}{ Granger Causality between Tourism Receipts and Economic Growth } \\
\hline Tourism-led growth & China, Germany, Turkey and the USA \\
\hline Growth-led tourism hypothesis & Spain and the UK \\
\hline Bidirectional causality & - \\
\hline No causality & France, Italy, Mexico, Russia and the panel of the analyzed countries \\
\hline \multicolumn{2}{|c|}{ Granger Causality between Tourism Receipts and Energy Consumption } \\
\hline Tourism-led energy & Turkey and the USA, \\
\hline Energy-led tourism & China, Mexico, Spain and the UK \\
\hline Bidirectional causality & The panel of the analyzed countries \\
\hline No causality & France, Germany, Italy and Russia \\
\hline
\end{tabular}

Please see the Appendix A for detailed test statistics from Emirmahmutoglu-Kose Granger causality approach.

\section{Conclusions and Policy Recommendation}

Energy and tourism have become among the most important sectors of the economy in the last several decades. As economic growth is the main indicator of the economy, it is of interest for researchers to focus on the relationship between the two most important sectors and economic growth. Thus, this empirical study aims to find the directions of Granger causality among tourism receipts and tourist arrivals, energy consumption and economic growth for the top 10 most-visited countries in the world. The top countries are responsible for about half of the world is tourism receipts, world tourist arrivals, world energy consumption and world income in the last years.

By using the Emirmahmutoglu-Kose bootstrap non-causality test, we found that an energy-led growth hypothesis is present in Spain, growth-led energy is present in China, Turkey and Germany, two-way causality is supported in Italy and the USA and no causal relationship is found between growth and energy in France, Mexico, Russia and the UK. By using the data for tourist arrivals a tourism-led growth hypothesis is present in China and Turkey a growth-led tourism hypothesis is found in Russia and Spain, bidirectional causality exists between growth and tourism in Germany, no causality occurs between the variables in France, Italy, Mexico, the UK and the USA. Tourism-led energy hypothesis is detected in Italy, Spain, Turkey, the UK and the USA an energy-led tourism hypothesis is found in China and Mexico and no causality is supported in France, Germany and Russia. By using the data for tourism receipts a tourism-led growth hypothesis exists in China, Germany, Turkey and the USA a growth-led tourism hypothesis occurs in Spain and the UK, and no Granger causality is detected in France, Italy, Mexico and Russia. Tourism-led energy hypothesis is present in Turkey and the USA an energy-led tourism hypothesis is supported in China, Mexico, Spain and the UK and no causal relationship is found in France, Germany, Italy and Russia. 
Our general policy implications are guidance for researchers and governments in order to build better tourism and energy strategies. From this perspective, empirical analysis like this study plays an important role for strengthening the energy-tourism-growth literature. In other words, energy consumption, tourism development and economic growth are strongly interrelated and cause one another. Therefore, policy makers of these countries should take sustainable energy and tourism policies into account for a sustainable economic growth. Similarly, the policy makers should also take a sustainable economic growth take into account for sustainable energy and tourism policies for their countries. This study reveals the need of further empirical studies using different methods on the energy consumption-tourism development-economic growth literature. These forthcoming studies will enable the policy makers and researchers to better understand the causal relationships between these variables.

Author Contributions: Cem Işık and Eyüp Doğan presents the basic ideas, introduction and obtains the main results in conducts, the illustration section also the whole paper; Serdar Ongan adds his contributions to the Sections 1 and 5 .

Conflicts of Interest: The authors declare no conflicts of interest.

\section{Appendix}

Table A1. Bootstrap Granger causality between energy consumption and economic growth.

\begin{tabular}{cccccc}
\hline & & \multicolumn{2}{c}{ Energy-Led Growth Hypothesis } & \multicolumn{2}{c}{ Growth-Led Energy Hypothesis } \\
\cline { 3 - 5 } & $\mathbf{k}_{\mathbf{i}}$ & Wald Test & $\boldsymbol{p}$-Value & Wald Test & $\boldsymbol{p}$-Value \\
\hline China & 2 & 0.74 & 0.69 & $4.69^{*}$ & 0.10 \\
France & 2 & 1.34 & 0.51 & 0.48 & 0.79 \\
Germany & 1 & 0.05 & 0.83 & $2.92^{*}$ & 0.09 \\
Italy & 1 & $6.86^{* * *}$ & 0.01 & $7.40 * * *$ & 0.01 \\
Mexico & 1 & 1.39 & 0.24 & 0.60 & 0.44 \\
Russia & 3 & $2.48^{* * *}$ & 0.48 & 4.58 & 0.21 \\
Spain & 1 & $6.23^{* * *}$ & 0.01 & 1.83 & 0.18 \\
Turkey & 1 & 0.92 & 0.34 & $5.35^{* *}$ & 0.02 \\
UK & 3 & 2.74 & 0.43 & 4.37 & 0.22 \\
USA & 3 & $23.97^{* * *}$ & 0.00 & $25.28^{* * *}$ & 0.00 \\
Panel & Fisher-stat & $\mathbf{5 0 . 0 3 * * *}$ & $\mathbf{0 . 0 0}$ & $\mathbf{6 1 . 5 6 * *}$ & $\mathbf{0 . 0 0}$ \\
\hline
\end{tabular}

Note: ${ }^{* * *}, * *$ and $*$ denote the statistical significance at $1 \%, 5 \%$ and $10 \%$ level of significance, respectively. $\mathrm{k}_{\mathrm{i}}$ is the maximum lag length.

Table A2. Bootstrap Granger causality between tourist arrivals and economic growth.

\begin{tabular}{cccccc}
\hline & & \multicolumn{2}{c}{ Tourism-Led Growth Hypothesis } & \multicolumn{2}{c}{ Growth-Led Tourism Hypothesis } \\
\cline { 3 - 6 } & $\mathbf{k}_{\mathbf{i}}$ & Wald Test & $\boldsymbol{p}$-Value & Wald Test & $p$-Value \\
\hline China & 1 & $5.08^{* *}$ & 0.02 & 0.02 & 0.89 \\
France & 1 & 0.18 & 0.67 & 0.20 & 0.65 \\
Germany & 1 & $7.69^{* * *}$ & 0.01 & $2.83^{*}$ & 0.09 \\
Italy & 1 & 2.40 & 0.12 & 0.06 & 0.80 \\
Mexico & 2 & 1.93 & 0.38 & 2.33 & 0.31 \\
Russia & 3 & 0.55 & 0.91 & $6.34^{*}$ & 0.10 \\
Spain & 3 & 0.79 & 0.85 & $7.58^{*}$ & 0.06 \\
Turkey & 2 & $5.94^{* *}$ & 0.05 & 0.84 & 0.66 \\
UK & 3 & 4.12 & 0.25 & 2.01 & 0.57 \\
USA & 2 & 1.18 & 0.55 & 2.26 & 0.32 \\
Panel & Fisher-stat & $\mathbf{3 5 . 1 9 * *}$ & $\mathbf{0 . 0 2}$ & $\mathbf{2 3 . 3 1}$ & $\mathbf{0 . 2 7}$ \\
\hline
\end{tabular}

Note: ${ }^{* * *},{ }^{* *}$ and ${ }^{*}$ denote the statistical significance at $1 \%, 5 \%$ and $10 \%$ level of significance, respectively. 
Table A3. Bootstrap Granger causality between energy consumption and tourist arrivals.

\begin{tabular}{cccccc}
\hline & & \multicolumn{2}{c}{ Tourism-Led Energy Hypothesis } & \multicolumn{2}{c}{ Energy-Led Tourism Hypothesis } \\
\cline { 3 - 6 } & $\mathbf{k}_{\mathbf{i}}$ & Wald Test & $\boldsymbol{p}$-Value & Wald Test & $\boldsymbol{p}$-Value \\
\hline China & 2 & 2.88 & 0.24 & $6.28^{* *}$ & 0.04 \\
France & 1 & 0.15 & 0.70 & 0.75 & 0.39 \\
Germany & 1 & 0.04 & 0.84 & 0.89 & 0.35 \\
Italy & 1 & $4.25^{* *}$ & 0.04 & 0.64 & 0.42 \\
Mexico & 2 & 0.87 & 0.65 & $10.89 * * *$ & 0.00 \\
Russia & 2 & 0.39 & 0.82 & 0.80 & 0.67 \\
Spain & 2 & $7.96^{* *}$ & 0.02 & 1.63 & 0.44 \\
Turkey & 2 & $16.62^{* * *}$ & 0.00 & 0.25 & 0.88 \\
UK & 3 & $28.05^{* * *}$ & 0.00 & 1.12 & 0.77 \\
USA & 1 & $4.18^{* *}$ & 0.04 & 0.98 & 0.32 \\
Panel & Fisher-stat & $\mathbf{6 7 . 7 6 ^ { * * * }}$ & $\mathbf{0 . 0 0}$ & $\mathbf{2 8 . 3 6}$ & $\mathbf{0 . 1 0}$ \\
\hline
\end{tabular}

Note: ${ }^{* * *}, * *$ and ${ }^{*}$ denote the statistical significance at $1 \%, 5 \%$ and $10 \%$ level of significance, respectively.

Table A4. Bootstrap Granger causality between tourism receipts and economic growth.

\begin{tabular}{cccccc}
\hline & & \multicolumn{2}{c}{ Tourism-Led Growth Hypothesis } & \multicolumn{2}{c}{ Growth-Led Tourism Hypothesis } \\
\cline { 3 - 6 } & $\mathbf{k}_{\mathbf{i}}$ & Wald Test & $\boldsymbol{p}$-Value & Wald Test & $\boldsymbol{p}$-Value \\
\hline China & 2 & $5.87^{* *}$ & 0.05 & 0.54 & 0.76 \\
France & 3 & 0.20 & 0.98 & 5.05 & 0.17 \\
Germany & 1 & $4.09^{* *}$ & 0.04 & 0.06 & 0.80 \\
Italy & 3 & 5.51 & 0.14 & 1.42 & 0.70 \\
Mexico & 1 & 0.14 & 0.70 & 2.02 & 0.16 \\
Russia & 3 & 1.62 & 0.65 & 5.05 & 0.17 \\
Spain & 3 & 5.43 & 0.14 & $36.57 * * *$ & 0.00 \\
Turkey & 3 & $32.04^{* * *}$ & 0.00 & 3.90 & 0.27 \\
UK & 1 & 0.38 & 0.54 & $2.92 *$ & 0.09 \\
USA & 2 & $13.10^{* * *}$ & 0.00 & 4.10 & 0.13 \\
Panel & Fisher-stat & $\mathbf{6 4 . 8 9 * *}$ & $\mathbf{0 . 0 0}$ & $\mathbf{5 7 . 4 8 * *}$ & $\mathbf{0 . 0 0}$ \\
\hline
\end{tabular}

Note: ${ }^{* * *},{ }^{* *}$ and ${ }^{*}$ denote the statistical significance at $1 \%, 5 \%$ and $10 \%$ level of significance, respectively.

Table A5. Bootstrap Granger causality between tourism receipts and energy consumption.

\begin{tabular}{cccccc}
\hline & & \multicolumn{2}{c}{ Tourism-Led Energy Hypothesis } & \multicolumn{2}{c}{ Energy-Led Tourism Hypothesis } \\
\cline { 3 - 6 } & $\mathbf{k}_{\mathbf{i}}$ & Wald Test & $\boldsymbol{p}$-Value & Wald Test & $\boldsymbol{p}$-Value \\
\hline China & 2 & 0.42 & 0.81 & $5.34^{*}$ & 0.07 \\
France & 3 & 4.13 & 0.25 & 1.41 & 0.70 \\
Germany & 2 & 2.57 & 0.28 & 0.57 & 0.75 \\
Italy & 3 & 3.84 & 0.28 & 3.25 & 0.35 \\
Mexico & 2 & 0.75 & 0.69 & $6.55^{* *}$ & 0.04 \\
Russia & 1 & 0.08 & 0.78 & 0.02 & 0.89 \\
Spain & 3 & 4.29 & 0.23 & $7.37^{*}$ & 0.06 \\
Turkey & 3 & $20.69^{* * *}$ & 0.00 & 1.38 & 0.71 \\
UK & 3 & 5.33 & 0.15 & $12.13^{* * *}$ & 0.01 \\
USA & 1 & $10.08^{* * *}$ & 0.00 & 1.11 & 0.29 \\
Panel & Fisher-stat & $\mathbf{4 7 . 3 2} * * *$ & $\mathbf{0 . 0 0}$ & $\mathbf{3 4 . 1 4}$ & $\mathbf{0 . 0 2}$ \\
\hline
\end{tabular}

Note: ${ }^{* * *}, * *$ and ${ }^{*}$ denote the statistical significance at $1 \%, 5 \%$ and $10 \%$ level of significance, respectively.

\section{References}

Adhikari, Dipa, and Yanying Chen. 2013. Energy consumption and economic growth: A panel cointegration analysis for developing countries. Review of Economics E Finance 3: 68-80. 
Akbostanc1, Elif, Gül İpek Tunç, and Serap Türüt-Aş1k. 2011. $\mathrm{CO}_{2}$ emissions of Turkish manufacturing industry: A decomposition analysis. Applied Energy 88: 2273-78. [CrossRef]

Al-mulali, Usama, Hassan Gholipour Fereidouni, Janice Y. M. Lee, and Abdul Hakim Mohammed. 2014. Estimating the tourism-led growth hypothesis: A case study of the Middle East countries. Anatolia 25: 290-98. [CrossRef]

Antonakakis, Nikolaos, Mina Dragounic, and George Filisd. 2015. Tourism and growth: The times they are a-changing. Annals of Tourism Research 50: 165-69. [CrossRef]

Aqeel, Anjum, and Mohammad Sabihuddin Butt. 2008. The relationship between energy consumption and economic growth in Pakistan. Asia Pacific Development Journal 8: 101-10.

Asif, Muhammad, and Tariq Muneer. 2007. Energy supply, its demand and security issues for developed and emerging economies. Renewable and Sustainable Energy Reviews 11: 1388-413. [CrossRef]

Azam, Muhammad, Abdul Qayyum Khan, B. Bakhtyar, and Chandra Emirullah. 2015a. The causal relationship between energy consumption and economic growth in the ASEAN-5 countries. Renewable $\mathcal{E}$ Sustainable Energy Reviews 47: 732-45.

Azam, Muhammad, Abdul Qayyum Khan, Khalid Zaman, and Mehboob Ahmad. 2015b. Factor determining energy consumption: Evidence from Indonesia, Malaysia and Thailand. Renewable and Sustainable Energy Reviews 42: 1123-31. [CrossRef]

British Petroleum Energy Outlook. 2015. Available online: http://www.bp.com/en/global/corporate/energyeconomics/energy-outlook-2035.html (accessed on 18 April 2016).

Chen, Sheng-Tung, Hsiao-I. Kuo, and C hi-Chung Chen. 2007. The relationship between GDP and electricity consumption in 10 Asian countries. Energy Policy 35: 2611-21. [CrossRef]

Cortes-Jimenez, Isabel, and Manuela Pulina. 2010. Inbound tourism and long run economic growth. Current Issues in Tourism 13: 61-74. [CrossRef]

Crouch, Geoffrey I., and Brent J. R. Ritchie. 1999. Tourism, Competitiveness, and Societal Prosperity. Journal of Business Research 44: 137-52. [CrossRef]

Daly, Herman E. 1991. Steady-State Economics: With New Essays. Washington, D.C.: Island Press.

Dogan, Eyup. 2014. Energy consumption and economic growth: Evidence from low-income countries in Sub-Saharan Africa. International Journal of Energy Economics and Policy 4: 154-62.

Dogan, Eyup. 2015. The relationship between economic growth and electricity consumption from renewable and non-renewable sources: A study of Turkey. Renewable and Sustainable Energy Reviews 52: 534-46. [CrossRef]

Dogan, Eyup, and Fahri Seker. 2016. The influence of real output, renewable and non-renewable energy, trade and financial development on carbon emissions in the top renewable energy countries. Renewable and Sustainable Energy Reviews 60: 1074-85. [CrossRef]

Dogan, Eyup, Fahri Seker, and Serap Bulbul. 2015. Investigating the impacts of energy consumption, real GDP, tourism and trade on $\mathrm{CO}_{2}$ emissions by accounting for cross-sectional dependence: A panel study of OECD countries. Current Issues in Tourism 20: 1701-19. [CrossRef]

Dogru, Tarik, and Umit Bulut. 2017. Is tourism an engine for economic recovery? Theory and empirical evidence. Tourism Management. in press. [CrossRef]

Dogru, Tarik, Umit Bulut, and Ercan Sirakaya-Turk. 2016. Resilience of Tourism Demand to Climate Change. Tourism Analysis 21: 645-60. [CrossRef]

Emirmahmutoglu, Furkan, and Nezir Kose. 2011. Testing for Granger causality in heterogeneous mixed panels. Economic Modelling 28: 870-76. [CrossRef]

Ertugrul, Hasan Murat, Murat Cetin, Fahri Seker, and Eyup Dogan. 2016. The impact of trade openness on global carbon dioxide emissions: Evidence from the top ten emitters among developing countries. Ecological Indicators 67: 543-55. [CrossRef]

Fisher, Ronald A. 1932. Statistical Methods for Research Workers, 4th ed.Edinburgh: Oliver and Boyd.

Hall, Colin Michael, and Stephen J. Page. 2014. The Geography of Tourism and Recreation: Environment, Place and Space. Abingdon: Routledge.

He, Li-Hua, and Xun-Gang Zheng. 2011. Empirical analysis on the relationship between tourism development and economic growth in Sichuan. Journal of Agricultural Science 3: 212-17. [CrossRef]

International Energy Agency (IEA). 2016. International Energy Statistics. Available online: https://www.eia.gov/beta/international/data/browser/\#/?pa =000000001\&c= ruvvvvvfvtvnvv1urvvvvfvvvvvvfvvvou20evvvvvvvvvnvvuvo\&ct=0\&vs=INTL.44-2-AFG-QBTU.A\&vo= $0 \& v=H \& e n d=2014$ (accessed on 18 April 2016). 
Isik, Cem. 2010. Natural gas consumption and economic growth in Turkey: A bound test approach. Energy Systems 1: 441-546. [CrossRef]

Isik, Cem. 2012. The USA's international travel demand and economic growth in Turkey: A causality analysis: (1990-2008). Tourismos: An International Multidisciplinary Journal of Tourism 7: 235-52.

Isik, Cem. 2013. The importance of creating a competitive advantage and investing in information technology for modern economies: An ARDL test approach from Turkey. Journal of the Knowledge Economy 4: 387-405. [CrossRef]

Isik, Cem. 2015. Foreign direct investment in tourism: panel data analysis of D7 countries. Athens Journal of Tourism 2: 93-103.

Işik, Cem, and Magdalena Radulescu. 2017a. Investigation of the Relationship between Renewable Energy, Tourism Receipts and Economic Growth in Europe. Statıstıka-Statıstıcs And Economy Journal 97: 85-94.

Işik, Cem, and Magdalena Radulescu. 2017b. Electricity-Growth Nexus in Turkey: The Importance of Capital and Labor. Revista Română de Statistică-Supliment nr 6: 230-44.

Isik, Cem, and Muhammad Shahbaz. 2015. Energy Consumption and Economic Growth: A Panel Data Approach to OECD Countries. International Journal of Energy Science 5: 1-5. [CrossRef]

Isik, Cem, Evangelia Kasımatı, and Serdar Ongan. 2017. Analyzing the causalities between economic growth, financial development, international trade, tourism expenditure and/on the $\mathrm{CO} 2$ emissions in Greece. Energy Sources, Part B: Economics, Planning, and Policy 7: 665-73. [CrossRef]

Isik, Cem, Tarik Dogru, and Ercan Sirakaya Turk. 2017. Nexus of linear and non-linear relationships between tourism demand, renewable energy consumption, and economic growth: Theory and evidence. International Journal of Tourism Research. 1-12. [CrossRef]

Jenkins, Katie, and Sarah Nicholls. 2010. The impacts of climate variability and potential climate change on tourism business in Torbay, England and implications for adaptation. Tourism Analysis 15: 17-30. [CrossRef]

Jin, Jang C. 2011. The effects of tourism on economic growth in Hong Kong. Cornell Hospitality Quarterly 52: 333-40. [CrossRef]

Kadir, Norsiah, and Mohd Zaini Abd Karim. 2012. Tourism and economic growth in Malaysia: Evidence from tourist arrivals from ASEAN-5 countries. Economic Research 25: 1089-100. [CrossRef]

Karabuğa, Arif, Melik Ziya Yakut, Gamze Yakut, Reşat Selbaş, and İbrahim Üçgül. 2015. Renewable Energy Solutions for Tourism. European Scientific Journal 11: 188-94.

Kareem, Olayinka Idowu. 2013. A reassessment of tourism-exports led growth hypothesis in Africa. American Journal of Tourism Research 2: 130-40. [CrossRef]

Katircioglu, Salih Turan, Mete Feridun, and Ceyhun Kilinc. 2014. Estimating tourism-induced energy consumption and $\mathrm{CO}_{2}$ emissions: The case of Cyprus. Renewable and Sustainable Energy Reviews 29: 634-40. [CrossRef]

Lee, Jung Wan, and Tantatape Brahmasrene. 2013. Investigating the influence of tourism on economic growth and carbon emissions: Evidence from panel analysis of the European Union. Tourism Management 38: 69-76. [CrossRef]

Lee, Jung Wan, and Michael Kwag. 2013. Green growth and sustainability: The role of tourism, travel and hospitality service industry in Korea. Journal of Distribution Science 11: 15-22. [CrossRef]

Leon, Carmelo J., Jorge E. Arana, and Anastasia Hernández Alemán. 2014. $\mathrm{CO}_{2}$ Emissions and tourism in developed and less developed countries. Applied Economics Letters 21: 1169-73. [CrossRef]

Liu, Jun, Tingting Feng, and Xi Yang. 2011. The energy requirements and carbon dioxide emissionsof tourism industry of Western China: A case of Chengdu city. Renewable and Sustainable Energy Reviews 15: 2887-94. [CrossRef]

Moutinho, Victor, Carlos Costa, and João Paulo Cerdeira Bento. 2015. The impact of energy efficiency and economic productivity on $\mathrm{CO}_{2}$ emission intensity in Portuguese tourism industries. Tourism Management Perspectives 16: 217-27. [CrossRef]

O'Mahony, Tadhg, Peng Zhou, and John Sweeney. 2012. The driving forces of change in energy related $\mathrm{CO}_{2}$ emissions in Ireland: A multi-sectoral decomposition from 1990 to 2007. Energy Policy 44: 256-67. [CrossRef]

Oh, Ilyoung, Walter Wehrmeyer, and Yacob Mulugetta. 2010. Decomposition analysis and mitigation strategies of $\mathrm{CO}_{2}$ emissions from energy consumption in South Korea. Energy Policy 38: 364-77. [CrossRef]

Ozturk, Ilhan. 2016. The relationships among tourism development, energy demand, and growth factors in developed and developing countries. International Journal of Sustainable Development $\mathcal{E}$ World Ecology 23: 122-31. 
Ozturk, Ilhan, Alper Aslan, and Huseyin Kalyoncu. 2010. Energy consumption and economic growth relationship: Evidence from panel data for low and middle income countries. Energy Policy 38: 4422-28. [CrossRef]

Pace, Lisa A. 2015. How do tourism firms innovate for sustainable energy consumption? A capabilities perspective on the adoption of energy efficiency in tourism accommodation establishments. Journal of Cleaner Production 11: 409-20. [CrossRef]

Pardo, Claudia Sheinbaum, Sergio Mora-Pérez, and Guillermo Robles Morales. 2012. Decomposition of energy consumption and $\mathrm{CO}_{2}$ emissions in Mexican manufacturing industries: Trends between 1990 and 2008. Energy for Sustainable Development 16: 57-67. [CrossRef]

Pesaran, M. Hashem. 2004. General diagnostic tests for cross section dependence in panels. University of Cambridge, Faculty of Economics. Cambridge Working Papers in Economics No. 0435; Cambridge, UK: University of Cambridge.

Rezitis, A. N., and S. M. Ahammad. 2015. Energy Consumption and Economic Growth in South and Southeast Asian Countries: Evidence from a Dynamic Panel Data Approach. International Energy Journal 15: 103-16.

Scott, Daniel. 2011. Why sustainable tourism must address climate change. Journal of Sustainable Tourism 19: 17-34. [CrossRef]

Scott, Daniel, and Susanne Becken. 2010. Adapting to climate change and climate policy: Progress, problems and potentials. Journal of Sustainable Tourism 18: 283-95. [CrossRef]

Shahbaz, Muhammad, and Hooi Hooi Lean. 2012. Does financial development increase energy consumption? The role of industrialization and urbanization in Tunisia. Energy Policy 40: 473-79. [CrossRef]

Sharpley, Richard, and David J. Telfer. 2015. Tourism and Development, Concepts and Issues, 2nd ed. Bristol: Channel View Publications.

Tang, Chor Foon, and Salah Abosedra. 2014. The impacts of tourism, energy consumption and political instability on economic growth in the MENA countries. Energy Policy 68: 458-64. [CrossRef]

Tang, Chor Foon, Aviral Kumar Tiwari, and Muhammad Shahbaz. 2016. Dynamic inter-relationships among tourism, economic growth and energy consumption in India. Geosystem Engneering. [CrossRef]

Tiwari, Aviral Kumar, Ilhan Ozturk, and M. Aruna. 2013. Tourism, energy consumption and climate change in OECD countries. International Journal of Energy Economics and Policy 3: 247-61.

Toda, Hiro Y., and Taku Yamamoto. 1995. Statistical inference in Vector Autoregressions with possibly integrated processes. Journal of Econometrics 66: 225-50. [CrossRef]

2013. United Nations World Tourism Organization (UNWTO). Available online: www.unwto.com (accessed on 18 April 2016).

2016. World Development Indicators (WDI). Available online: data.worldbank.org (accessed on 18 April 2016).

Wolde-Rufael, Yemane. 2004. Disaggregated industrial energy consumption and GDP: The case of Shanghai, 1952-1999. Energy Economics 26: 69-75. [CrossRef]

$\mathrm{Wu}, \mathrm{Pu}$, and Peihua Shi. 2011. An estimation of energy consumption and $\mathrm{CO}_{2}$ emissions in tourism sector of China. Journal of Geographical Sciences 21: 733-45. [CrossRef]

Yuan, Jiahai, Changhong Zhao, Shunkun Yu, and Zhaoguang Hu. 2007. Electricity consumption and economic growth in China: cointegration and co-feature analysis. Energy Economics 29: 1179-91. [CrossRef]

(C) 2017 by the authors. Licensee MDPI, Basel, Switzerland. This article is an open access article distributed under the terms and conditions of the Creative Commons Attribution (CC BY) license (http://creativecommons.org/licenses/by/4.0/). 